\title{
Evaluation of sediment management for two large reservoirs in Lombok island
}

\author{
Ery Setiawan ${ }^{1}$, Syamsul Hidayat ${ }^{1, *}$, Ida Bagus Giri Putra ${ }^{1}$, Muhammad Bagus Budianto ${ }^{1}$, \\ and Salehudin ${ }^{1}$
}

${ }^{1}$ Civil Engineering Department, Faculty of Engineering, University of Mataram

\begin{abstract}
Sedimentation is an important issue in reservoir rehabilitation and maintenance. This problem is worsened by seasonal water scarcity as a characteristic of arid catchments. Worldwide loss of storage capacity due to sedimentation is much higher than the increase of capacity by the construction of new reservoirs. Further, sedimentation hinders the safe operation of not only shallow reservoirs but also deep reservoirs by means of turbidity currents which sporadically transport large volumes of sediments down to the dams. This study analyses the real case of Pengga reservoir and Batujai reservoir located in Central Indonesia. Selected sediment management alternatives were analysed and evaluated based on technical, social and environmental criteria. Evaluation of sediment management alternatives was conducted by utilising the REServoir CONservation (RESCON) tool. Results showed that, first, both flushing techniques and hydrosuction are feasible whereas dredging and trucking are not. Secondly, the flushing technique outweighs the Hydrosuction Sediment Removal (HSRS) method. Thirdly, application of the HSRS method in both reservoirs shares one thing in common, i.e. it requires an appropriate combination of the number of suction pipes as well as minimum suction pipe diameters. Lastly, there are some differences in the details of implementation of the flushing technique to both reservoirs.
\end{abstract}

\section{Introduction}

Economic growth requires the development of water resources including hydraulic structures such as dams. Many have been built and operated to regulate natural runoff which transports not only water but also sediment. The latter, in turn, causes severe loss of reservoir capacity through sedimentation and deposition. The difficulty to find sites for potential new dams for future development has frustrated efforts to maintain economic growth as well as to maintain settlements supported by reservoirs.

The provision of "dead storage" indicates that the sedimentation issues were recognised from the very beginning of water resources development. Such storages were aimed to accommodate sufficient space for the incoming sediments during the reservoirs' lifetime. It has been observed, however, that when the reservoirs were resurveyed years later, the sedimentation rate was higher than what was calculated during the preliminary design stage.

\footnotetext{
* Corresponding author: syamsul.hidayat@unram.ac.id
} 
The loss of reservoir capacity results in less reliable municipal, industrial and irrigation supply, less hydropower generated, and increasing flood damage. It can be concluded that reservoir sedimentation is a serious issue for water resource development. Therefore, viable sediment management techniques need to be assessed before being implemented in order to ensure sustainable reservoir operation, rehabilitation and maintenance.

Quite a significant number of studies have been conducted on the management of reservoir sedimentation in Indonesia [1,2] non-structural sedimentation management [3], or a review of sedimentation management as done by [4]. Despite the availability of appropriate mathematical models, little to no studies employ these tools. Utilising a mathematical model has advantages such as clearer assumptions, more objective calculations and ease in replication compared to manual assessments.

The present work is aimed to evaluate selected sediment management alternatives in terms of technical and economical viewpoints. The REServoir CONservation (RESCON) developed by [5] and [6] was adopted in assessing available sediment management alternatives including the "do-nothing", flushing method, hydrosuction technique, dredging and trucking. RESCON has been used worldwide (see for example, [7] and [8]) in assessing sediment management alternatives.

\section{Study reservoirs}

Pengga reservoir and Batujai reservoir are two main reservoirs in Lombok Island. The former is located at the downstream of the latter, constituting reservoirs in series (Figure 1).

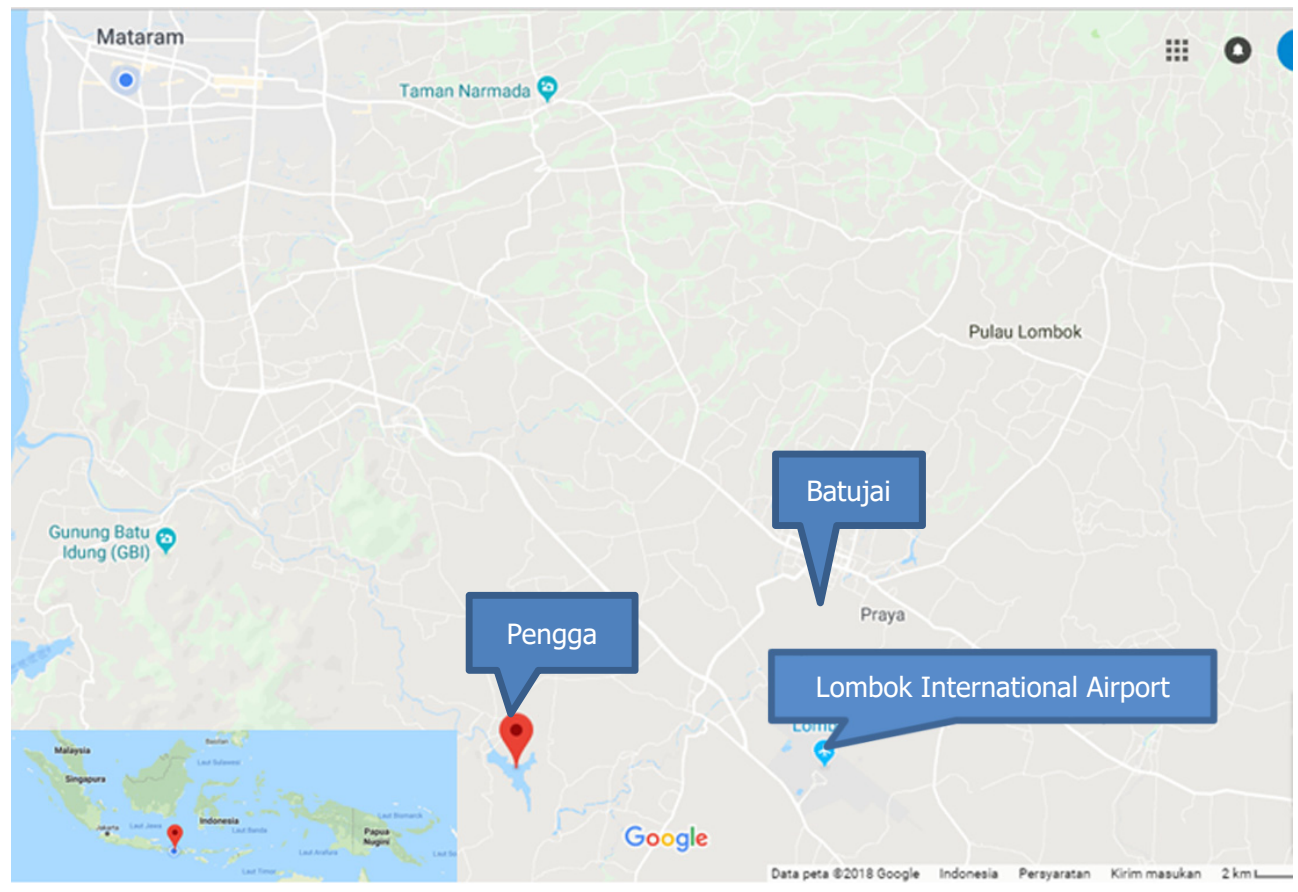

Fig. 1. Study reservoirs (source [10], viewed on 30-July-2018). 


\section{Methodology}

\subsection{User input sheets}

The RESCON model provides two sheets for data input. In the first sheet, the input data includes reservoir geometry, water characteristics, sediment characteristics, removal parameters, economic parameters, flushing benefit parameters and capital investment. Those in the second sheet include safeguard ratings for each sediment removal technology, safeguard policy criteria as well as estimated social and environmental levels. Safeguardrelated data and estimated social and environmental levels are beyond the scope of the present study so the comparison of sediment management alternatives is merely based on data for the first sheet.

Table 1. Geometry of Pengga reservoir and Batujai reservoir.

\begin{tabular}{|c|c|c|c|c|c|}
\hline Parameter & Units & Sources & Parameter & Units & Sources \\
\hline $\mathrm{S}_{\mathrm{o}}$ & $\left(\mathrm{m}^{3}\right)$ & {$[8]$} & $\mathrm{EL}_{\text {min }}$ & $(\mathrm{m})$ & {$[9]$} \\
\hline $\mathrm{S}_{\mathrm{e}}$ & $\left(\mathrm{m}^{3}\right)$ & {$[8]$} & $\mathrm{EL}_{\mathrm{f}}$ & $(\mathrm{m})$ & Equal to ELmin \\
\hline $\mathrm{W}_{\mathrm{bot}}$ & $(\mathrm{m})$ & {$[7]$} & $\mathrm{L}$ & $(\mathrm{m})$ & {$[9]$} \\
\hline $\mathrm{SS}_{\text {res }}$ & & {$[7]$} & $\mathrm{h}$ & $(\mathrm{m})$ & {$[9]$} \\
\hline $\mathrm{EL}_{\max }$ & $(\mathrm{m})$ & {$[7]$} & & & \\
\hline
\end{tabular}

Dam water elevation during flushing was varied in past studies such as in Rashid et al. (2014). In the present work, however, this parameter was set equal to the minimum elevation $\left(\mathrm{El}_{\mathrm{min}}\right)$.

Table 2. Water characteristics of Pengga reservoir and Batujai reservoir.

\begin{tabular}{|c|c|c|}
\hline Parameters & Units & Sources \\
\hline $\mathrm{V}_{\text {in }}$ & $\left(\mathrm{m}^{3}\right)$ & Based on inflow from 1982-2017 (Batujai) and 1994-2017 (Pengga) \\
\hline $\mathrm{C}_{\mathrm{V}}$ & $\left(\mathrm{m}^{3}\right)$ & As above \\
\hline $\mathrm{T}$ & $\left({ }^{\circ} \mathrm{C}\right)$ & {$[11]$} \\
\hline
\end{tabular}

Table 3. Sediment characteristics of Batujai reservoir and Pengga reservoir taken from [11].

\begin{tabular}{|c|c|}
\hline Parameters & Units \\
\hline$\rho_{\mathrm{d}}$ & $\left(\right.$ tonnes $\left./ \mathrm{m}^{3}\right)$ \\
\hline $\mathrm{M}_{\text {in }}$ & $($ metric tonnes $)$ \\
\hline$\Psi$ & $650\left(10 \mathrm{~m}^{3} / \mathrm{s}<\mathrm{Q}_{\mathrm{f}}<3,000 \mathrm{~m} 3 / \mathrm{s}\right), 180\left(\mathrm{Q}_{\mathrm{f}}<50 \mathrm{~m}^{3} / \mathrm{s}\right)$ \\
\hline Brune Curve No & 3 \\
\hline Ans & 1 \\
\hline Type & 1 \\
\hline
\end{tabular}

Table 4. Economic parameters of Pengga reservoir and Batujai reservoir, default values were taken from [5] and [6].

\begin{tabular}{|c|c|c|c|c|c|}
\hline Parameter & Units & Value & Parameter & Units & Value \\
\hline $\mathrm{E}$ & 0 or 1 & 0 & $\mathrm{~V}$ & $(\$)$ & 0 \\
\hline $\mathrm{c}$ & $\left(\$ / \mathrm{m}^{3}\right)$ & 1.75 & omc & & 0.01 \\
\hline $\mathrm{C}_{2}$ & $(\$)$ & 0 & $\mathrm{PH}$ & $\left(\$ / \mathrm{m}^{3}\right)$ & 0.02 \\
\hline $\mathrm{r}$ & decimal & 0.07 & $\mathrm{PD}$ & $\left(\$ / \mathrm{m}^{3}\right)$ & 0.02 \\
\hline $\mathrm{Mr}$ & decimal & 0.07 & $\mathrm{CD}$ & $\left(\$ / \mathrm{m}^{3}\right)$ & 3.00 \\
\hline $\mathrm{P}_{1}$ & $\left(\$ / \mathrm{m}^{3}\right)$ & 0.2 & $\mathrm{CT}$ & $\left(\$ / \mathrm{m}^{3}\right)$ & 13.00 \\
\hline
\end{tabular}


Table 5. Removal parameters of Pengga reservoir and Batujai reservoir, default values were taken from [5] and [6].

\begin{tabular}{|c|c|c|}
\hline Parameters & Units/options & Sources and default values \\
\hline $\mathrm{HP}$ & 1 & {$[8]$} \\
\hline $\mathrm{Q}_{\mathrm{f}}$ & $\left(\mathrm{m}^{3} / \mathrm{s}\right)$ & $10-3,000 \mathrm{~m}^{3} / \mathrm{s}$ \\
\hline $\mathrm{T}_{\mathrm{f}}$ & $($ days $)$ & 1 day -2 months \\
\hline $\mathrm{N}$ & (years) & $1-15$ years \\
\hline $\mathrm{D}$ & (feet) & $1-4 \mathrm{ft}$ \\
\hline $\mathrm{NP}$ & 1,2, or 3 & 1,2 or 3 \\
\hline YA & Between 0 and 1 & $0-1$ \\
\hline CLF & $(\%)$ & Greater than capacity lost already \\
\hline CLH & $(\%)$ & Greater than capacity lost already \\
\hline CLD & $(\%)$ & Greater than capacity lost already \\
\hline CLT & $(\%)$ & Greater than capacity lost already \\
\hline ASD & $(\%)$ & $0-100$ \\
\hline AST & $(\%)$ & $0-100$ \\
\hline MD & $(\mathrm{m} 3)$ & $1,000,000$ \\
\hline MT & $(\mathrm{m} 3)$ & 500,000 \\
\hline CW & $(\%)$ & 30 \\
\hline
\end{tabular}

Table 6. Flushing benefit parameters of Pengga reservoir and Batujai reservoir, default values were taken from [5] and [6].

\begin{tabular}{|l|l|l|c|}
\hline $\mathrm{s}_{1}$ & decimal & $\begin{array}{l}\text { The fraction of Run-of-River benefits available in the year flushing occurs } \\
\text { (s1 ranges from 0 to 1). }\end{array}$ & 0.9 \\
\hline $\mathrm{s}_{2}$ & decimal & $\begin{array}{l}\text { The fraction of storage benefits available in the year flushing occurs (s2 } \\
\text { ranges from 0 to1). }\end{array}$ & 0.9 \\
\hline
\end{tabular}

Table 7. Capital investments of Pengga reservoir and Batujai reservoir, default values were taken from [5] and [6].

\begin{tabular}{|c|c|l|c|}
\hline FI & $\$$ & $\begin{array}{l}\text { Cost of capital investment required for implementing flushing measures. } \\
\text { The cost entered will be incurred when fliushing is first practiced. }\end{array}$ & 50 \\
\hline HI & $\$$ & $\begin{array}{l}\text { Cost of capital investment to install Hydrosuction Sediment-Removal } \\
\text { Systems (HSRS). }\end{array}$ & 20 \\
\hline DU & Years & The expected life of HSRS. & 25 \\
\hline
\end{tabular}

\section{Results and discussions}

The results calculated by RESCON involve the calculation of flushing technique, HSRS technique, safeguard, as well as economic results and conclusions. As the scope of the present study is to conduct an evaluation based on economic and technical grounds, only economic results and conclusions are presented in Table 8 and Table 9 for Batujai reservoir and Pengga reservoir, respectively.

It can be seen that in all cases, in general the feasibility of sediment management alternatives yield the same results for both reservoirs. Total removals by HSRS, dredging and trucking are not feasible for Batujai and Pengga, with the latter having another infeasible alternative, i.e. do nothing. 
Table 8. Economic results and conclusions for Batujai reservoir.

\begin{tabular}{|l|c|c|}
\hline \multicolumn{1}{|c|}{ Possible Strategies } & Technique & $\begin{array}{c}\text { Aggregate Net } \\
\text { Present Value }\end{array}$ \\
\hline Do nothing & N/A & IDR 2,331,169.29 \\
\hline $\begin{array}{l}\text { Nonsustainable (Decommissioning) with Partial } \\
\text { Removal }\end{array}$ & HSRS & IDR 2,331,169.29 \\
\hline Nonsustainable (Run-of-River) with No Removal & N/A & IDR 2,226,923.75 \\
\hline Nonsustainable (Run-of-River) with Partial Removal & HSRS & IDR 2,226,923.75 \\
\hline Sustainable & Flushing & IDR 2,641,009.16 \\
\hline Sustainable & HSRS & $\begin{array}{c}\text { Total Removal with } \\
\text { HSRS is technically } \\
\text { infeasible, See Partial } \\
\text { Removal with HSRS }\end{array}$ \\
\hline Sustainable & -IDR 12,802,914.60 \\
\hline Sustainable & Dredging & -IDR 33,013,087.09 \\
\hline
\end{tabular}

The rest of the alternatives for both reservoirs produced slight economic advantages over others, with the flushing technique provides the highest aggregate net benefit. Implementation of this technique to Batujai reservoir, however, is considered to be more flexible as the flushing discharge might vary from lower values compared to those of Pengga.

Meanwhile, application of the HSRS method to both reservoirs should be done cautiously as there are appropriate combinations of the number of pipes (ND parameter) with the suction pipes' diameters (D parameter). Either one should be set higher in order to make this technique feasible. Other parameters that must also be set carefully are YA (kept to zero) so that partial removal is feasible, and CLF (set to $100 \%$ ).

Table 9. Economic results and conclusions for Pengga reservoir.

\begin{tabular}{|l|c|c|}
\hline \multicolumn{1}{|c|}{ Possible Strategies } & Technique & Aggregate Net Present Value \\
\hline Do nothing & N/A & IDR 2,331,169.29 \\
\hline $\begin{array}{l}\text { Nonsustainable } \\
\text { (Decommissioning) with } \\
\text { Partial Removal }\end{array}$ & HSRS & IDR 2,331,169.29 \\
\hline $\begin{array}{l}\text { Nonsustainable (Run-of-River) } \\
\text { with No Removal }\end{array}$ & N/A & IDR 2,226,923.75 \\
\hline $\begin{array}{l}\text { Nonsustainable (Run-of-River) } \\
\text { with Partial Removal }\end{array}$ & HSRS & IDR 2,226,923.75 \\
\hline Sustainable & Flushing & IDR 2,641,009.16 \\
\hline Sustainable & HSRS & $\begin{array}{l}\text { Total Removal with HSRS is technically } \\
\text { infeasible, See Partial Removal with HSRS }\end{array}$ \\
\hline Sustainable & Dredging & -IDR 12,802,914.60 \\
\hline Sustainable & Trucking & -IDR 33,013,087.09 \\
\hline
\end{tabular}

The grant for international publications by Department of Civil Engineering, Faculty of Engineering, University of Mataram is gratefully acknowledged.

\section{References}

1. D. A. Wulandari, Sedimentation management of Mrica reservoir (in Indonesian). Teknik Keairan, 13, 264-271. (2004)

2. Suroso, and W. Widiyanto, Sedimentation control model of Mrica reservoir using fluidization (in Indonesian). Dinamika Rekayasa, 5, 50-56. (2009) 
3. A. Wahid, Analysis of sedimentation characteristics of the Bakaru Hydropower (in Indonesian). Jurnal Hutan dan Masyarakat, 2, 229-236. (2010)

4. T. Marhendi, Management strategy to reservoir sedimentation (in Indonesian). Techno, 14, 29-41. (2013)

5. S. Kawashima, T.B. Johndrow, G.W. Annandale, F. Shah, Reservoir conservation, Volume-II: RESCON model and user manual, The World Bank. (2003)

6. A. Palmieri, F. Shah, G.W. Annandale, A. Dinar, Reservoir conservation, Volume-I: The RESCON approach, The World Bank. (2003)

7. Y. Lee, F. Shah, Economics of sustainable watershed management under alternative climate change scenarios. (2009)

8. S. Rulot, B.J. Dewals, S. Erpicum, P. Archambeau, M. Pirotton, Long-term sediment management for sustainable hydropower. (2012)

9. I. Kasiro, Isdiana, D. Pangluar, C. Nugroho, A. Muchtar, H. Martadi, R. Suryadilaga, Large dams in Indonesia (in Indonesian), Ministry of Public Works, Jakarta. (1995)

10. BWS NT I, Data and information on water resources management of Lombok Greater Basin and Sumbawa Greater Basin (in Indonesian), Mataram.

11. Office of Operation and Maintenance, Operation of Pengga reservoir and Batujai reservoir, Central Lombok Regency Office of Operation and Maintenance of Batujai reservoir and Pengga reservoir, Praya. (2017) 